Олійник О. О. ${ }^{[1 ; ~ O R C I D ~ I D: ~ 0000-0002-3941-2286], ~}$ к.е.н., доцент

${ }^{1}$ Національний університет водного господарства та природокористування, м. Рівне

\title{
ПРОТИДІЯ ДОМАШНЬОМУ НАСИЛЬСТВУ НА ЗАСАДАХ КОРПОРАТИВНОЇ СОЦІАЛЬНОЇ ВІДПОВІДАЛЬНОСТІ
}

В статті досліджено сутність та форми домашнього насильства. Проаналізовано рівень поширення домашнього насильства серед населення України, визначено його вплив та наслідки на трудову сферу. Обґрунтовано заходи в межах корпоративної соціальної відповідальності для протидії домашньому насильству та підтримки постраждалих.

Ключові слова: домашнє насильство; соціальна відповідальність; переслідування; гендерна рівність; дискримінація; гендерні стереотипи.

Постановка проблеми. Проблема домашнього насильства постає достатньо гострою для усіх країн світу, зокрема через нерівність в розподілі повноважень і ресурсів між жінками та чоловіками, наявними гендерними стереотипами в суспільстві тощо. 3 метою запобіганню цьому ганебному явищу в Глобальні Цілі сталого розвитку, які були затверджені у 2015 році на саміті ООН 3 питань сталого розвитку, було включено Ціль 5 «Забезпечення гендерної рівності, розширення прав і можливостей усіх жінок та дівчаток» [1]. Хоча деякі показники гендерної рівності демонструють позитивну динаміку, наприклад простежується значне зменшення випадків раннього одруження, загальний рівень нерівності продовжує залишатись високим. Така ж тенденція характерна і для підцілі 5.2 «Ліквідувати всі форми насильства щодо всіх жінок і дівчаток у публічній і приватній сферах, включаючи торгівлю людьми, сексуальну та інші форми експлуатації». Останні дані з 106 країн свідчать, що 18\% жінок та дівчат віком від 15 до 49 років зазнали фізичного та/або сексуального насильства протягом попередніх 12 місяців. В найменш розвинених країнах цей показник сягає $24 \%$ [2]. Таким чином, домашнє насильство - це глобальна соціальна проблема, яка здійснює негативний вплив на всі аспекти життєдіяльності суспільства, призводить до значних соціальних та економічних витрат та втрат. Для прикладу, в Бельгії насильство 3 боку партнерів коштує 439 мільйонів євро на рік, 3 яких 288 мільйонів є виробничими втратами через простої, прогули тощо. 
Разом 3 тим, 35\% відсотків жінок, які постраждали від домашнього насильства, зазнали значних труднощів у досягненні своїх професійних цілей внаслідок втрати концентрації, втоми, депресії, дратівливості, посттравматичного стресового розладу, параної, тривожності. Окрім значного психологічного дискомфорту, всі ці фактори призводять до втрати продуктивності праці, демотивації колег та сторонніх осіб, зростає рівень абсентеїзму, що сприяє поширеності ризику втрати роботи та безробіття [3]. За таких умов, дослідження питання гендерної рівності та запобігання домашньому насильству на засадах корпоративної соціальної відповідальності $\epsilon$ актуальним науковим завданням.

Аналіз останніх досліджень та публікацій. Дослідженню проблематики гендерної рівності та протидії домашньому насильству присвячені публікації таких науковців, як О. Бойко, І. Ієрусалимова, М. Маєрчик, Т. Марценюк, О. Плахотнік, М. Саприкіна, Я. Юрків та ін. Однак, незважаючи на значну кількість науково-методичних праць в цій сфері, побудова та розвиток системи запобігання домашньому насильству не набула достатньо широкого практичного застосування на теренах вітчизняного бізнес-середовища. Відтак дослідження перспектив використання корпоративної соціальної відповідальності у якості інструменту протидії домашньому насильству $€$ актуальним науковим завданням.

Метою роботи $€$ дослідження поширеності домашнього насильства та можливостей його запобігання на засадах корпоративної соціальної відповідальності.

Виклад основного матеріалу. Відповідно до Закону України «Про запобігання та протидію домашньому насильству», під цим поняттям слід розуміти діяння (дії або бездіяльність) фізичного, сексуального, психологічного або економічного насильства, що вчиняються в сім"ї чи в межах місця проживання або між родичами, або між колишнім чи теперішнім подружжям, або між іншими особами, які спільно проживають (проживали) однією сім'єю, але не перебувають (не перебували) у родинних відносинах чи у шлюбі між собою, незалежно від того, чи проживає (проживала) особа, яка вчинила домашнє насильство, у тому самому місці, що й постраждала особа, а також погрози вчинення таких діянь [4].

Запропонований підхід дозволяє виокремити такі форми домашнього насильства [4]:

1) фізичне насильство - ляпаси, стусани, штовхання, щипання, шмагання, кусання, а також незаконне позбавлення волі, нанесення побоїв, мордування, заподіяння тілесних ушкоджень різного ступеня 
тяжкості, залишення в небезпеці, ненадання допомоги особі, яка перебуває в небезпечному для життя стані, заподіяння смерті, вчинення інших правопорушень насильницького характеру;

2) психологічне насильство - словесні образи, погрози, у тому числі щодо третіх осіб, приниження, переслідування, залякування, інші діяння, спрямовані на обмеження волевиявлення особи, контроль у репродуктивній сфері, якщо такі дії або бездіяльність викликали у постраждалої особи побоювання за свою безпеку чи безпеку третіх осіб, спричинили емоційну невпевненість, нездатність захистити себе або завдали шкоди психічному здоров'ю особи;

3) сексуальне насильство - будь-які діяння сексуального характеру, вчинені стосовно повнолітньої особи без ії згоди або стосовно дитини незалежно від їі згоди, або в присутності дитини, примушування до акту сексуального характеру з третьою особою, а також інші правопорушення проти статевої свободи чи статевої недоторканості особи, у тому числі вчинені стосовно дитини або в її присутності;

4) економічне насильство - умисне позбавлення житла, їжі, одягу, іншого майна, коштів чи документів або можливості користуватися ними, залишення без догляду чи піклування, перешкоджання в отриманні необхідних послуг з лікування чи реабілітації, заборону працювати, примушування до праці, заборону навчатися та інші правопорушення економічного характеру.

Проблематика домашнього насильства у різних формах його прояву сьогодні набула глобального характеру. Не можуть протидіяти цьому явищу і у високорозвинених країнах світу. Так, щороку понад 10 мільйонів чоловіків і жінок у США піддаються домашньому насильству:

- 35,6\% жінок та 28,5\% чоловіків у США повідомляють про зґвалтування, фізичне насильство та/або переслідування партнером протягом свого життя;

- насильство зі сторони партнера становить 15\% усіх насильницьких злочинів;

- $81 \%$ жінок та 35\% чоловіків, які зазнали зґвалтування, переслідування або фізичного насильства 3 боку партнера, мали значні коротко- чи довгострокові наслідки, такі як симптоми посттравматичного стресового розладу та травми [5].

В Австралії кожна третя жінка зазнала фізичного насильства 3 часу свого 15-річного віку. При цьому представниці жіночої статі в п'ять разів частіше ніж чоловіки потребують медичної допомоги або госпіталізації внаслідок домашнього насильства. Як результат, в цій 
країні в середньому принаймні одну жінку щотижня вбиває теперішній або колишній партнер [6].

Факти домашнього насильства характерні також і для України. За результатами соціологічного дослідження, здійсненого за фінансової підтримки уряду Великої Британії на замовлення UNFPA, Фонду ООН у галузі народонаселення, у співпраці 3 Центром «Розвиток КСВ» [7], особистий досвід домашнього насильства мали $24 \%$ працівників і працівниць компаній в Україні. При цьому основною формою було психологічне насильство (19\%): образи, погрози, приниження, шантаж із боку членів родини контроль за колом спілкування, телефонними дзвінками, обмеження пересування, переслідування 3 боку члена родини (нав'язливі дзвінки, стеження тощо). 14\% постраждалих зазнавали побиття або тілесних ушкоджень. 4\% респондентів забороняли працювати, позбавляли засобів для існування, відбирали гроші чи майно. Прояв сексуального насильства відчули на собі $2 \%$ опитаних. При цьому основними кривдниками були колишній партнер/ка (42\%), мати/батько (34\%), теперішній партнер/ка (25\%). Водночас 91\% чоловіків та $74 \%$ жінок, які піддавались домашньому насильству, не звертались до жодних організацій за допомогою.

Оскільки серед опитаних, які визнали, що їм доводилося стикатися із домашнім насильством, переважну більшість становили представниці жіночої статі, доцільно більш ґрунтовно дослідити ризики насильства саме щодо цієї категорії населення. Так, результати дослідження, проведеного під керівництвом Організації з безпеки та співробітництва в Європі (ОБСЄ) демонструють, що дві третини (67\%) жінок України у віці 15 років і старшому зазнали психологічного, фізичного або сексуального насильства з боку інтимного партнера або іншої особи [8, С. 12]. При цьому найбільш поширеною формою є саме психологічне насильство (рис. 1).

Другий щабель займають сексуальні домагання: майже половина опитаних жінок мали такий негативний досвід. Водночас вагома меншість жінок погодилася, що секс без згоди допустимий в окремих ситуаціях. Приблизно кожна п'ята жінка (19\%) вважає, що це виправдано в шлюбі або між партнерами, які живуть разом (для жінок старших ніж 60 років цей показник зростає до 25\%), кожна шоста жінка - якщо жінка за власним бажанням іде з кимось додому $(16 \%) ;$ те ж, якщо чітко не каже «ні» чи не чинить фізичного опору (16\%); або якщо перед тим відбувся флірт (15\%). 


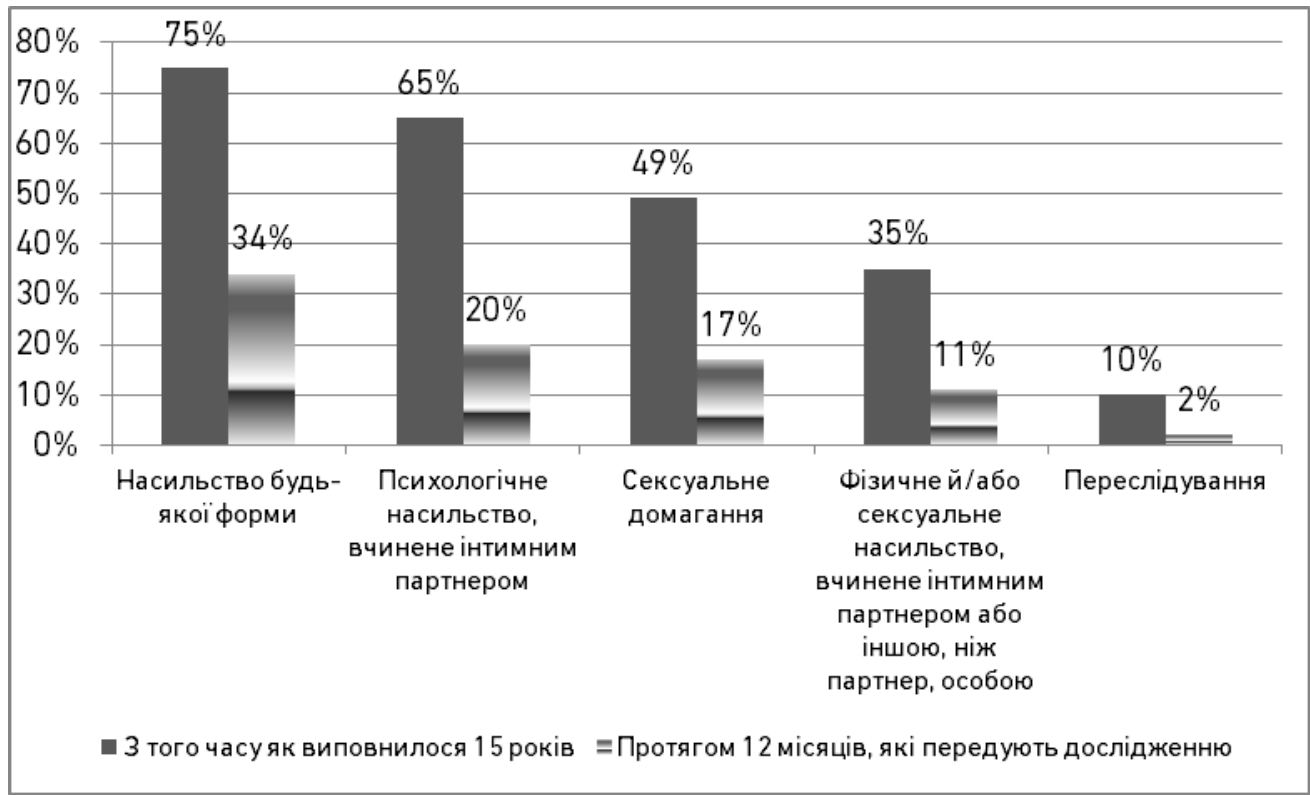

Рис. 1. Рівень поширення різних форм насильства над жінками Джерело: складено за даними [8]

Фізичному чи/або сексуальному насильству піддавалась кожна третя жінка. При цьому приблизно чверть жінок в Україні вважає, що домашнє насильство - це особиста справа й має вирішуватись у межах сім"і (26\%). Це вище за середній показник в Європейському Союзі (14\%), але нижче за показник сусідньої Румунії (31\%). У країнах ЄС показник згоди з таким твердженням варіюється від 2\% у Швеції до $31 \%$ у Румунії [9]. Це свідчить про існування певних гендерних стереотипів в окремих країнах, а також про те, що у країнах 3 високим рівнем інформаційної політики щодо питань гендерної рівності жінки виявляють більше бажання говорити про домашнє насильство.

Кожна десята жінка (10\%) стверджує, що вона зазнала переслідування, найпоширенішою формою якого було те, що хтось вештався біля ії дому. Окрім того, жінкам надсилали електронні листи, текстові повідомлення 3 образами або погрозами чи телефонували, озвучуючи подібний зміст; за ними навмисно слідували; або хтось навмисно шкодив чи псував їхнє майно.

Фізичний та психологічний стан жертв домашнього насильства не залишається непоміченим членами трудового колективу: $41 \%$ працівників та працівниць помічали ознаки домашнього насильства в колективі, а кожен 7 респондент особисто знайомий із такою жертвою. Викликає значного занепокоєння той факт, що найбільш 140 
поширеними доказами домашнього насильства серед працівників $€$ саме очевидні ушкодження, такі як порізи, сліди від ударів, гематоми, опіки, переломи, що часто пояснюються колегам як наслідки «випадкових падінь», «власної незграбності» або «нещасних випадків» (рис. 2).

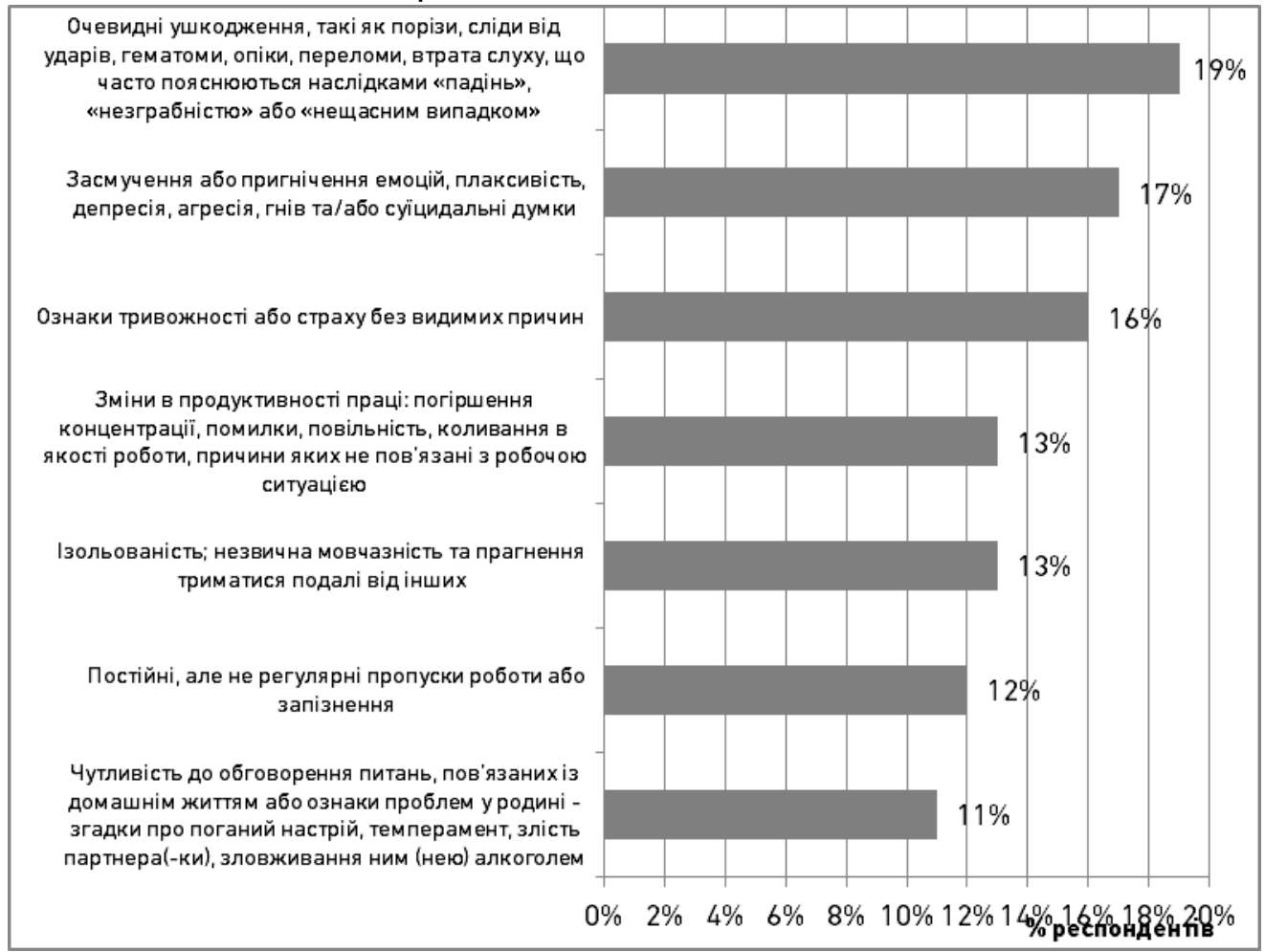

Рис. 2. Найбільш поширені ознаки домашнього насильства, які респондент(к)и розпізнавали в поведінці власних колег

Джерело: складено за даними [7]

Серед інших ознак, які можуть «натякати» на нещодавній досвід домашнього насильства, зазначали зміни в рівні вживання алкоголю або медичних препаратів, використання одягу, що не відповідає сезону (наприклад, довгі рукави або високі комірці влітку), сонцезахисних окулярів у приміщенні, надмірно щільний макіяж, незвичні прохання щодо організації робочого часу, незвична кількість вхідних телефонних дзвінків та небажання на них відповідати, раптові візити партнера або партнерки, несподівана поява подарунків або квітів на робочому місці тощо. Як показав більш глибокий кореляційний аналіз результатів опитування, 
наведені ознаки домашнього насильства помітно краще розпізнають ті люди, яким самим доводилося стикатися з цими проблемами [7].

Як наслідок, через домашнє насильство $26 \%$ жертв довелось змінити місце проживання, а $24 \%$ зазнали значних економічних наслідків - втратили заробіток чи дохід, що зумовлено тимчасовою непрацездатністю (рис. 3).

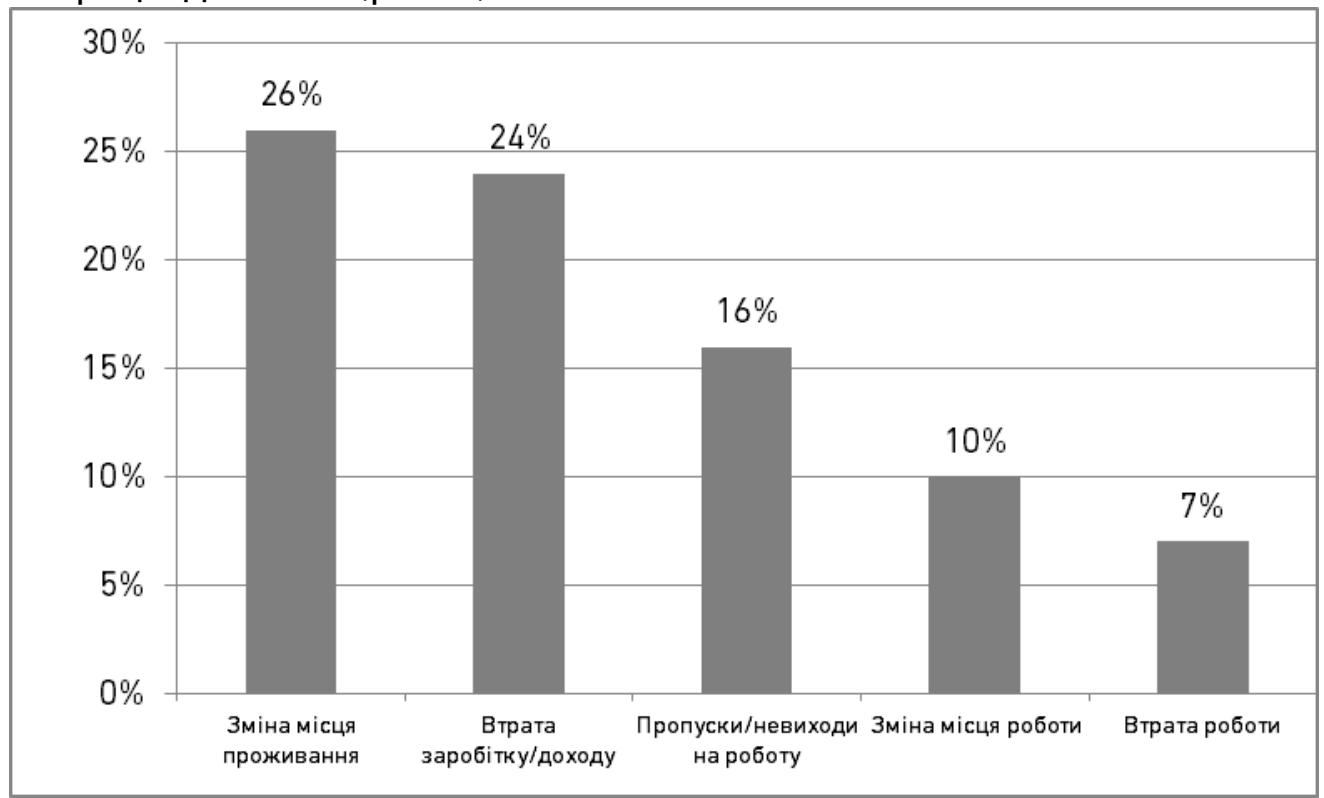

Рис. 3. Наслідки домашнього насильства

Джерело: складено за даними [7]

Окрім того, кожний десятий постраждалий змінив місце роботи, передумовою чого могло стати небажання розголосу та обговорення цієї ситуації в трудовому колективі. 7\% були звільнені через, те, що не змогли опанувати себе після насильницького інциденту i, як наслідок, не змогли виконувати свої професійні обов'язки на належному рівні.

Окрім серйозних наслідків для людини-жертви домашнього насильства, це явище здійснює негативний вплив на ефективність діяльності компанії загалом та ії бізнес-репутацію. Наприклад, у дослідженні в Папуа-Новій Гвінеї, де насильство на гендерній основі широко поширене, підрахували, що працівники втрачають в середньому 11 робочих днів на рік внаслідок домашнього насильства: два - презентаціонізм, п'ять - через прогули та чотири надання допомоги іншим жертвам насильства. Скорочення робочого часу персоналу коштує компаніям від 3 до 9 відсотків заробітної плати [10]. 
Застосування європейських підходів до оцінювання наслідків насильства щодо жінок в Україні показало, що сукупні економічні втрати суспільства можуть сягати до 208 млн дол. США на рік. Хоча основна частина цих збитків пов'язана з особистими витратами постраждалих від насильства жінок, втрати економічного продукту через їхню непрацездатність були оцінені майже в 4 млн дол. США на рік. Більше того, в умовах значного поширення неформальної зайнятості розмір цих збитків може бути суттєво заниженим, оскільки розрахунки ґрунтувалися на даних офіційної статистики ринку праці, включаючи рівень зайнятості та розмір заробітної плати [7].

За таких умов компанії в Україні повинні звернути увагу на проблему домашнього насильства та перейняти на себе важливу роль у боротьбі з різними формами насильства щодо жінок. Відтак, розробка корпоративних заходів щодо захисту здоров'я, безпеки та благополуччя персоналу, забезпечення гендерної рівності повинні стати складовою бізнес-стратегії та стратегії корпоративної соціальної відповідальності. Зарубіжний досвід свідчить, що такий підхід може реалізовуватись у різний спосіб: залежно від виду діяльності, цільової групи споживачів, місії, філософії та цінностей компанії. При цьому використовуються як традиційні гендерні практики (розробка гендерної політики, навчання та тренінги, просвітницькі заходи тощо), так і інноваційні [10; 11; 12]. Для прикладу, компанія IKEA використала соціальний експеримент для привернення уваги покупців до проблеми домашнього насильства. «Домашнє насильство ближче, чим ви думаєте. Іноді вас розділяє всього лише стіна» - це ключове повідомлення соціального експерименту, коли в одному з італійських магазинів IKEA в стіну вмонтували динамік, з якого доносилися звуки сімейної сварки і побоїв.

Інший яскравий приклад - телеком-оператор Vodafone. $\mathrm{y}$ Туреччині одна з трьох жінок зазнає домашнього насильства, і спеціально для них бренд розробив додаток Red Light. 3 його допомогою жінка може потай від чоловіка покликати на допомогу: достатньо потрясти телефоном, і додаток розішле повідомлення із закликом про допомогу і геомітками. При цьому повідомлення відправляється не в поліцію, а трьом близьким людям, яким довіряє потерпіла, тому що для багатьох східних жінок звернення в поліцію 3 приводу насильства від близьких родичів категорично неприйнятно.

Оновлення комунікаційної платформи 3 метою протидії домашньому насильству реалізував мексиканський пивний бренд 
Tecate Beer, який з 1944 року позиціонує себе як «пиво для чоловіків». Цілком ймовірно, що серед його цільової аудиторії може бути велика кількість абьюзерів. Тому Тесаtе роз'яснює, що чоловік може бути будь-яким, але «якщо ви не знаєте, як поводитися 3 жінками, ви не заслуговуєте Тесаtе». Інформаційна кампанія велася як на телебаченні, в інтернеті, так і в місцях продажів пива Tecate, де висіли постери, що нагадують про ключове повідомлення бренду.

Висновки. Таким чином, сьогодні існує потреба у підвищенні обізнаності та покращення розуміння того, яким чином бізнессередовище може долучитися до вирішення проблеми домашнього насильства та які заходи на засадах корпоративної соціальної відповідальності слід реалізовувати у цьому напрямку. 3-поміж останніх можна виокремити:

- формування мережі психологічної та/або юридичної допомоги для працівників компанії;

- організація та проведення профілактичних заходів, семінарів, тренінгів щодо запобігання домашньому насильству;

- включення ризику домашнього насильства в корпоративні програми медичного страхування;

- поширення інформації щодо наявних «гарячих» ліній підтримки, адрес та телефонів спеціалізованих установ, які надають послуги постраждалим.

1. Цілі сталого розвитку 2016-2030. URL: http: //www.un.org.ua/ua/tsili-rozvytkutysiacholittia/tsili-staloho-rozvytku (дата звернення: 12.02.2020). 2. Report of the Secretary-General on SDG Progress 2019 Special Edition. New York, 2019. 64 p. 3. Involvement of companies in the fight against gender-based violence. National study for Belgium. URL: http://www.pourlasolidarite.eu/sites/default/files/ carve_belgianstudy_en.pdf (дата звернення: 12.02.2020). 4. Про запобігання та протидію домашньому насильству : Закон України від 07.12.2017 р. № 2229-VIII. URL: https://zakon.rada.gov.ua/laws/show/2229-19 (дата звернення: 12.02.2020). 5. 20 Alarming Domestic Violence Statistics for 2018. URL: https://www.socialsolutions.com/blog/domestic-violence-statistics-2018/ (дата звернення: 10.02.2020). 6. Domestic Violence Statistics. URL: https://www.whiteribbon.org.au/understand-domestic-violence/facts-violencewomen/domestic-violence-statistics/ (дата звернення: 12.02.2020). 7. Гендерна рівність та відповідь на домашнє насильство у приватному секторі в Україні: заклик до дій. URL: https://ukraine.unfpa.org/sites/default/files/pubpdf/maket_u.pdf (дата звернення: 12.02.2020). 8. Добробут і безпека жінок. Дослідження насильства над жінками в Україні. Київ, 2018. 120 с. 9. Special Eurobarometer 449: Gender-based violence. URL: https://data.europa.eu/euodp/en/data/dataset/ S2115_85_3_449_ENG (дата звернення: 10.02.2020). 10. A. Allan. How Businesses Can Take the Lead in Combatting Gender-Based Violence. URL: https://ssir.org/articles/entry/how_businesses_can_take_the_lead_in_combatting_ge nder_based_violence (дата звернення: 12.02.2020). 11. Як великий, середній та 
малий бізнес виграє від політики рівності та запобігання домашньому насильству. URL: https://ukraine.unfpa.org/sites/default/files/pubpdf/Gender_brochure_200x200 _16_01_19.pdf (дата звернення: 10.02.2020). 12. Tecate: Gender Violence. URL: https://www.warc.com/content/paywall/article/

warcawards/tecate_gender_violence/120520 (дата звернення: 12.02.2020).

\section{REFERENCES:}

1. Tsili staloho rozvytku 2016-2030. URL: http: //www.un.org.ua/ua/tsili-rozvytkutysiacholittia/tsili-staloho-rozvytku (data zvernennia: 12.02.2020). 2. Report of the Secretary-General on SDG Progress 2019 Special Edition. New York, 2019. 64 r. 3. Involvement of companies in the fight against gender-based violence. National study for Belgium. URL: http://www.pourlasolidarite.eu/sites/default/files/ carve_belgianstudy_en.pdf (data zvernennia: 12.02.2020). 4. Pro zapobihannia ta protydiu domashnomu nasylstvu : Zakon Ukrainy vid 07.12.2017 r. № 2229-VIII. URL: https://zakon.rada.gov.ua/laws/show/2229-19 (data zvernennia: 12.02.2020). 5. 20 Alarming Domestic Violence Statistics for 2018. URL: https://www.socialsolutions.com/blog/domestic-violence-statistics-2018/ (data zvernennia: 10.02.2020). 6. Domestic Violence Statistics. URL: https://www.whiteribbon.org.au/understand-domestic-violence/facts-violencewomen/domestic-violence-statistics/ (data zvernennia: 12.02.2020). 7. Henderna rivnist ta vidpovid na domashnie nasylstvo u pryvatnomu sektori v Ukraini: zaklyk do dii. URL: https://ukraine.unfpa.org/sites/default/files/pub-pdf/maket_u.pdf (data zvernennia: 12.02.2020). 8. Dobrobut i bezpeka zhinok. Doslidzhennia nasylstva nad zhinkamy v Ukraini. Kyiv, 2018. 120 s. 9. Special Eurobarometer 449: Gender-based violence. URL: https://data.europa.eu/euodp/en/data/dataset/ S2115_85_3_449_ENG (data zvernennia: 10.02.2020). 10. A. Allan. How Businesses Can Take the Lead in Combatting Gender-Based Violence. URL: https://ssir.org/articles/entry/how_businesses_can_take_the_lead_in_combatting_ge nder_based_violence (data zvernennia: 12.02.2020). 11. Yak velykyi, serednii ta malyi biznes vyhraie vid polityky rivnosti ta zapobihannia domashnomu nasylstvu. URL: https://ukraine.unfpa.org/sites/default/files/pubpdf/ Gender_brochure_200x200 _16_01_19.pdf (data zvernennia: 10.02.2020). 12. Tecate: Gender Violence. URL: https://www.warc.com/content/paywall/article/

warcawards/tecate_gender_violence/120520 (data zvernennia: 12.02.2020). 


\section{COMBATING DOMESTIC VIOLENCE BY VIRTUE OF CORPORATE SOCIAL RESPONSIBILITY}

The paper investigates the nature and forms of domestic violence. The author clearly substantiates that the issue of domestic violence in its various forms has become global today. The article analysed the level of domestic violence among the population of Ukraine. It is determined that $24 \%$ of female and male employees of companies in Ukraine had such negative personal experience. The main form was coercive control / emotional or psychological abuse (19\%), $14 \%$ of the victims experienced physical abuse, i.e. were beaten or injured, $4 \%$ of respondents were forbidden to work, deprived of their livelihoods, robbed of money or property. The foremost offenders included former partners $(42 \%)$, mother / father $(34 \%)$, and current partners $(25 \%)$. At the same time, $91 \%$ of men and $74 \%$ of women who were victims of domestic violence did not seek help from any organisations. Colleagues at work clearly notice the physical and psychological status of the victims of domestic violence, in particular: $41 \%$ of employees noticed the signs of domestic violence among the staff members, and every $7^{\text {th }}$ respondent was personally familiar with the victim. Domestic violence caused $26 \%$ of victims to change their place of residence, and $24 \%$ suffered significant economic consequences, i.e. lost income or profits. The research determined that in addition to the serious consequences for the victim of domestic violence, this phenomenon has a negative impact on the effectiveness of the company as a whole and its business reputation. The application of European approaches to assessing the impact of violence against women in Ukraine has revealed that the total economic losses of society can reach up to $\$ 208$ million per year. Under these conditions, companies in Ukraine need to address the issue of domestic violence and take an important role in combating various forms of violence against women. The paper substantiates corporate social responsibility activities to combat domestic violence and support victims.

Keywords: domestic violence; social responsibility; persecution; gender equality; discrimination; gender stereotypes. 
Олейник Е. А. ${ }^{[1 ; 0 R C I D ~ I D: ~ 0000-0002-3941-2286], ~}$ к.э.н., доцент

${ }^{1}$ Национальный университет водного хозяйства и природопользования, г. Ровно

\section{ПРОТИВОДЕЙСТВИЕ ДОМАШНЕМУ НАСИЛИЮ НА ОСНОВЕ КОРПОРАТИВНОЙ СОЦИАЛЬНОЙ ОТВЕТСТВЕННОСТИ}

В статье исследована сущность и формы домашнего насилия. Проанализирован уровень распространения домашнего насилия среди населения Украины, определены его влияние и последствия на трудовую сферу. Обоснованы мероприятия в рамках корпоративной социальной ответственности для противодействия домашнему насилию и поддержки пострадавших.

Ключевые слова: домашнее насилие; социальная ответственность; преследования; гендерное равенство; дискриминация; гендерные стереотипы. 